\title{
Entrepreneurship and Image Management in Higher Education: Pillars of Massification
}

\section{JOAN MOUNT}

Laurentian University

CHARLES H. BÉLANGER

Laurentian University

\section{ABSTRACT}

Mass higher education has taken hold in the developed nations, and a widely held belief exists that higher education is a "right." With massification have emerged two notable trends: an entrepreneurial emphasis fuelled by the revenue-cost squeeze ensuing from reduced and realigned government funding; and a quest for differentiation through "Image Management" and even "Branding," given the multitude of institutions and offerings present in the "postmassification" era. This paper examines this evolution, some say "revolution," in the university sector.

\section{RÉSUMÉ}

L'enseignement supérieur de masse s'est imposé dans les pays industrialisés et est largement considéré comme un « droit ». 
Cet accès universel a entraîné deux phénomènes notables : d'une part un accent sur l'entrepreneuriat justifié par la réduction du financement gouvernemental et l'obligation d'assumer les coûts de fonctionnement; d'autre part, la nécessité que le grand nombre d'établissements et de programmes qui ont facilité cette universalité se distinguent individuellement en recourant à la «gestion de l'image » et même à la création d'une «marque de commerce ». Cet article examine cette évolution, ou même « révolution » comme certains la qualifient, dans le secteur universitaire.

\section{INTRODUCTION}

The last three decades have seen an increasing responsiveness to contextual imperatives in the higher education sphere, in many cases market-centered. Have they really brought what Kerr (1987) has cast as "the greatest critical age for universities on a worldwide basis in eight centuries" (p. 184)? The author of The Idea of a University (1852), Cardinal John Newman, would no doubt chastise the university of today as having sold out for mammon. For him, as for many others still, it would be, and is, inconceivable that the university become other than a community of thinkers deliberately distant from the vortex of the world. On the other hand, Krachenberg (1972) asserted that "As with all social institutions ... a university must be alert to the danger of being so far removed from society that it ceases to be a viable entity in that social system" (p. 373). Some have described the present shift as a "revolution" (Jencks \& Riesman, 1968; Kirp, 2003). This paper attempts to unpack some key facets of this shift and to pose some timely questions.

From a socioeconomic perspective, the history of higher education in the twentieth century constitutes a transposition from 
education for a privileged few, primarily males, to broader access under the pressure of the post-war consumer economy. The rhetoric over time has highlighted both the public good, and the private good. Increasingly, the goal is seen to be that of providing a country's citizens - all of its citizens - with the ability to realize their full potential (Dobson, 2001).

Social justice and the principle of equal opportunity aside, proponents of the human capital theory have argued that open access to tertiary education optimizes the available talent pool and with it, a nation's economic competitiveness. If education is broadly available, either free or at an affordable price, there will be more people gainfully employed to support the national economy and, not to be overlooked, the national tax base.

Educational policies became the preferred [government] weapon for raising the general qualifications of the national working population as well as its mobility and for producing an adequate labour force with certain types of key qualifications. (Carrier, 1990, p. 91)

Given the advent of the "knowledge economy," the rationale of late often speaks to national competitiveness in a global context (Abele, 1992; ACST, 1999; De la Mothe, 1998; Etzkowitz \& Leydesdoff, 1997; Soley, 1996). In this vein Teichler (2001) points out that:

The widespread concern prevailing in the past about "overeducation" or "over-qualification" gave way in the 1990s to views that further expansion ... might be an appropriate foundation of a "knowledge society." (p. 4)

To foster success in the "knowledge economy," in some cases the government has shaped teaching areas directly by such actions as flowing funds specifically to engineering technology and computer science. While not the subject of this paper, recent "challenge and 
matching" funding competitions, which support applied research most particularly in science, technology, and health, speak to the power of the government to influence the academic research agenda. This thrust is anchored in a conviction, broadly held by the citizenry at large, that the tertiary education sector can materially enhance participation in the global marketplace. Critics claim that this activity bodes grave consequences for the less applied disciplines and in particular for the Arts (e.g., Currie \& Newson, 1998). Arguably it diverts energy, as well, from basic research in the target domains.

- A Question to Ponder: Will institutions of higher education be tempted to narrow their spectrum of scholarship because of funding opportunities and consequent image enhancement, at the expense of comprehensive programming and flexible, inclusive admission requirements? The present current augurs for excellence and greater specialization, both as a magnet for funding and as a means of differentiation from peer institutions.

Consideration of this question calls for a close examination of the philosophy of mass access to higher education (the "why"), and of the phenomenon itself (the "what").

\section{THE DYNAMICS OF MASSIFICATION}

\section{Massification}

The term "mass higher education," or massification, has been employed to describe the growth of enrolment "beyond the level of academic reproduction and training for a small number of occupations requiring this education for demanding professions and privileged social positions" (Teichler, 1998). It is commonly linked to the proportion of new entrant students, normally youth aged 25 and under, at "institutions of higher education." The interval from the mid-1970s to the late 1980 s came to be known as the

The Canadian Journal of Higher Education

Volume XXXIV, No. 2, 2004 
"era of maturation," and the subsequent period as the "era of postmassification." While there is some variation in the definition of "higher education," a generally accepted threshold for massification is $15 \%$ (Trow, 1970). Post-massification, now the hallmark of the developed nations, is defined in terms of a higher education system that provides access to more than half of the new entrant cohort.

Broad access normally involves a varied menu of programmes, flexible admission requirements, multiple points of entry and exit, a broader spectrum of student preparedness, and in some countries free tuition. Overall, this permeability spawns diversity in student background, ability, and motivation. Some institutions, most notably those with highly developed research profiles or professional programs of exceptional repute, exercise their capability to impose preemptive entrance standards. In contrast, others are committed to a policy of open access on societal grounds. Some of those who espouse open access are admittedly hungry for tuition dollars. Inevitably post-massification brings with it issues of image and reputation, and of cost, among others. Questions about retention and rates of completion, the breakeven point for "remedial" initiatives, and the cost of dropouts to the institution and to society at large are the grist of post-massification.

A prominent dimension related to the open doors of academe, at growing cost, is the mounting demand seen in the U.S.A. and other parts of the developed world for accountability and efficiency (Alexander, 1998). Lewis, Hendel, and Dundar (2002) voice an increasingly prevalent perspective: "The State clearly has a regulatory role to ensure that education providers (public and private) meet certain quality and equity standards in all higher education institutions" (pp. 41-42).

Governments, moreover, are now taking measures, i.e., instituting some form of Taxpayer Protection and Balanced Budget Act, to ban deficits on the part of publicly funded institutions. If universities do 
not exhibit fiscal responsibility, through publicly verifiable avenues of accountability, the State is ready to act. Concomitantly, governments have reduced operating grants to higher education institutions.

Further, the higher education sector is confronted by other realities, equally dramatic. As early as 1972, writers began to argue the merits of "marketing" higher education (Fram, 1972; Krachenberg, 1972). A generation later the parlance of marketing is firmly entrenched in the vocabulary of administrators of post-secondary institutions. Issues around "positional advantage" are reinforced frontally for universities as each year academic administrators peruse Maclean's ratings and most recently, those of the Globe and Mail. Those institutions that fare badly in the "game of prestige" know all too well what it can mean to the size and quality of student intake and, albeit less linearly, to faculty recruitment. Moreover, the advent of a new "sales tool," the Internet, has revolutionized student choice. Now the cultivation of "reputation" and "mindshare" are tied, tellingly, to website presentation and personalized, interactive follow-up. Also on the horizon are the new industry-driven universities such as the Technical University of British Columbia and the Ontario University Institute of Technology that specialize in "market-ready" professional education. While the first mentioned is now closed and the second at the time of writing has not acquired university status, these institutions are nonetheless symptomatic of the current times which have spawned "for-profit" universities in the United States. Prominent among these last are the University of Phoenix and DeVry University, which offer accredited professional programs with considerable appeal in this country, as well. Ruch (2001) points out that one can now find universities listed on stock exchanges as far flung as Johannesburg, Bombay, and New York.

While the imperatives, including market dynamics to which the universities must respond, are not of their making and may not be of 
their choice, nonetheless they constitute real pressures. Consequently, entrepreneurship and image management - the latter often leading to a quest for a "unique selling proposition" with the hallmarks of a "brand"- have become characteristic of the current age of postmassification. In the discussion that follows, these elements will be examined in the context of universities.

- A Question to Ponder: To what extent can universities cater to student preferences and yet pass on culture, perspective, and a spirit of critical inquiry? In the university of Cardinal Newman, students came as acolytes to absorb the scholarly heritage of wisdom and to develop their own intellectual capacities for critical reflection. Many would argue today that the core elements of the more traditional university are no longer adequately safeguarded. Others assert on either philosophical or practical grounds the need for an integrative, rather than purist, approach.

This question begs a knowledge of two rising currents that have become more and more intertwined in the sphere of higher education: an entrepreneurial orientation and a close attention to image.

\section{Entrepreneurship}

Concurrently with broad access, there has been a decrease in direct government support for higher education in many jurisdictions. In Canadian universities focused on arts and science programs, tuition fees now cover on average around $40 \%$ of the operating costs. Nevertheless the Association of Universities and Colleges of Canada (AUCC) stated in 1999 that rises in tuition fees, which have been substantial in some jurisdictions, have offset only $40 \%$ of the government support lost since 1990 . Not surprisingly, ancillary revenues are increasingly a cornerstone of university budgets for very pragmatic reasons. University presidents state that the time-honoured role of academia must be protected and 
preserved (Mount \& Bélanger, 2001), and yet they also know that budget deficits are seldom condoned. Dwindling or more targeted government support, often combined with government-mandated tuition limits, has forced their institutions to be more cost conscious and also to become entrepreneurial (Berman, 1998; Clark, 1998a \& b). Terms such as "academic capitalism," the "entrepreneurial university," and the "enterprise university" are labels applied by Slaughter and Leslie (1997) and Marginson and Considine (2000), respectively. Institutional heads have little choice if they are to attain balanced budgets.

Stated in simplistic terms (the authors' own), the operative equation is $\mathrm{G}+\mathrm{T}+\mathrm{aR}=\mathrm{C}$ where $\mathrm{G}$ is Government funding, $\mathrm{T}$ is tuition, aR is ancillary Revenue, and $\mathrm{C}$ is Cost. In this formula, $\mathrm{T}$ in some aspects, and $\mathrm{aR}$ in particular, are hospitable to entrepreneurial initiatives. Clark (1998b) observed that an "entrepreneurial response offers a formula for institutional development that puts autonomy on a self-defined basis." In particular, it reduces "governmental dependency" and it counter-balances the capability that government has at determining the adequacy of available resources (Eastman, 2003).

One can find many areas in the tertiary education sector where the entrepreneurial impetus asserts itself. The gamut includes deliberate attention to special markets which permit differential fees; proactive retention strategies; development of products with student appeal; competitive financial support for the individual student; pursuit of donorship and sponsorship opportunities; and honing of grantsmanship. Many universities are active in all areas. Against a backdrop of marked inter-institutional competition, specialists are often hired into positions specific to revenue generating activities. Clark (2002) underlined the reliance of universities on a growing number of non-faculty professionals. Depending on the 
institution, there may also be income generation from a number of specific sources which could include royalties from patents and commercialization of inventions, and proceeds from conferences, special events, and rental of facilities.

- A Question to Ponder: Given that the entrepreneurial climate in universities today is compatible with and even encouraging to "academic entrepreneurs" who do proprietary contract research, is the concept of a community of scholars, openly discussing research findings and ideas, being eroded? This is a question that taps Marginson and Considine's musings (2000, p.6) about the university as an institution "losing sight of its own distinctive features and achievements, losing control over the very means by which its own identity is formed."

\section{Image Management}

Recently, too, there is a clearer recognition of the importance of image management, extending to the desire to establish a "brand" that will be particular to the institution. Image and reputation have become highly marketable commodities, assisting as they do to differentiate institutions one from another and enhance the marketability of a given institution's offerings. Just as an entrepreneurial focus is a fitting and indeed necessary response to the revenue-cost dilemma, so, too, is the impetus to stand out amidst the plethora of institutions and offerings that mark the post-massification era.

Lucrative niche target groups, particularly the international student and the working professional, gravitate to a "name," and an image. Hatch and Schultz (2000) are among those who have noted that organizations, universities being a case in point, are asking themselves simple, but difficult questions such as: "How do we discover our identity?" Other researchers (van Riel, 1997, 2000) are attempting to provide guidance for the task of developing a corporate image. 
The concept of image is not only important for attaining lucrative niche markets. One can argue that it is equally vital for attracting and retaining the main stream of students. Arecent survey of undergraduates suggests that students are looking for value for tuition, which includes an academic climate that fosters new ideas and is motivating (Bélanger, Mount, \& Wilson, 2002). Closely associated with overall image are the specific products offered. Universities are increasingly eager to mount programs that will stand out and achieve their own brand recognition. Here again elements of market analysis come into play - for example, students and parents alike place a value on employment prospects; not surprisingly, a recent survey of university presidents (Mount \& Bélanger, 2001) suggests that University heads regard the addition of CO-OP/ Work Study placements as an attractive programming feature. The concepts of image management, product differentiation, and competitive advantage may be foreign discourse, even anathema, in academic circles. Nonetheless, they are basic ingredients in the new entrepreneurial fight to stay solvent.

Attracting students to enroll is essential, but not sufficient. Numerous researchers (Levitz, Noel, \& Richter, 1999; Murtaugh, Burns, \& Schuster, 1999; Pascarella, 1982; Terkla \& Pagano, 1993) report that retention rates are closely related to image. Failure to offer the student the university experience that he or she expects to find at the given institution invites dissonance that can lead to alienation and withdrawal. Likely examples would be classes at a given institution substantially larger than anticipated, and/or an environment a lot less safe than expected. Meeting student expectations, and hence protecting the university's image, combined with proactive student retention strategies, have become avenues to minimize erosion of tuition revenues and in some cases of government grants. Consider that completion rates can exercise an explicit impact on government funding, as recently seen in Ontario. ${ }^{1}$ 
Further, the more diverse the student body, described by Clark (1998b) as "endless 'clienteles' entitled to different types of education in their lifetimes," the more varied the expectations. Clearly, too, students and potential students are but one stakeholder group. Equally present are employees including faculty, alumni, parents, government agencies, philanthropists, industrial partners and so on. The challenge is to project a coherent, consistent image that will resonate with all audiences, knowing that they often overlap.

- A Question to Ponder: Is it desirable and are we willing to accept that the established university has been overtaken by the higher education "industry" to such an extent that institutional priorities are now substantially shaped and determined by external stakeholders, including prospective students and corporations? Now, wooed over the Internet, students are regarded as "customers" who can all too easily be lured away by what they perceive to be a better offer.

\section{CONCLUSION}

For both philosophical and pragmatic reasons, massification merging into post-massification has occurred in the developed world, with attendant benefits to individuals and nations. In the external environment are two dynamics of note. One is an emphasis on industry-supported research. The other is an onus to provide measurable results, typically on externally determined dimensions. At the same time, shrinking government funding and escalating operating costs propel tertiary sector administrators to seek new, and even controversial, avenues to expand their funding base. "Entrepreneurship" and increasingly "image management" have become watchwords of the post-massification era and are mutually reinforcing. They also may spawn unintended consequences. 
In the U.S., a setting where market forces and commercialization have leapt to the fore, thinkers such as Soley (1996), Kirp (2003), and Bok (2003) give voice in the current decade, as others have before, to issues about the identity and long-term health of academia. Kirp (2003) sums up the situation faced by universities.

New educational technologies; a generation of students with different desires and faculty with different demands; a new breed of rivals that live or die by the market; the incessant demand for more funds and new revenue sources to replace the ever-shrinking proportion of public support; a genuinely global market in minds; taken together these forces are remaking the university ...(p. 6)

He then adds incisively, "Still, embedded in the very idea of the university... are values that the market does not honor" (p. 7), and elsewhere asks, "Will sociology and comparative literature, and pure mathematics too, become the 'dead languages' of the millenium?" (p. 261).

In Canada, while the factors summarized above may be less pronounced, is it realistic or even possible to ignore government pressures and corporate urgings, or to spurn the marketplace? Recognizing the strength of the tide, compelling questions call for earnest, collective reflection. Policy makers, both inside and outside academia, must ponder these questions if they seek to preserve the essence of universities as untrammeled intellectual havens, and yet help these institutions to survive in the present era. It is essential that universities, and particularly their heads, not deny the threat that exists to the core elements of the traditional university. At the same time, they cannot dodge the insistent thrust and the fiscal dynamic of the new entrepreneurial university. With massification has come a dramatic set of identity questions that must be faced. 


\section{Notes}

${ }^{1}$ In 2000 , the Provincial Government inaugurated a distribution pattern in Ontario, where there are nineteen universities, which specifically linked the anticipated increase in government funding to Completion Rates and Employment Success. Universities in the top third of these two criteria would receive two thirds of the designated provincial funding increase. Universities in the middle third would share the remaining third of that increase, and those universities in the bottom third would lose out. The spread in performance results was relatively small, and yet this competitive funding formula immediately created winners and losers.

\section{References}

Abele, F. (1992). The politics of competitiveness. In F. Abele (Ed.), How Ottawa spends, 1992-93. Ottawa: Carleton University Press.

ACST - (Prime Minister's) Advisory Council on Science and Technology. (1999). Public investments in university research. Ottawa, ON: Government of Canada.

Alexander, F.K. (1998). The endless pursuit of efficiency: The international movement to increase accountability and performance in higher education. Miami, Fl.: Annual Meeting of the Association for the Study of Higher Education. 18 p. (ED427585).

AUCC - Association of Universities and Colleges of Canada. (1999). Trends. Ottawa, Canada: Author.

Bélanger, C.H., Mount, J., \& Wilson, M. (2002). Institutional image and retention. Tertiary Education and Management, 8(3), 217-230.

Berman, E.H. (1998). The entrepreneurial university-macro and micro perspectives from the United States. In J. Currie \& J. Newson (Eds.), Universities and globalization-critical perspectives. Thousand Oaks, California: Sage Publications.

Bok, D. (2003). Universities in the market place: The commercialization of higher education. Princeton, N.J.: Princeton University Press. 
Carrier, D. (1990). Legislation as a stimulus to innovation. Higher Education Management, 2(1), 88-98.

Clark, B.R. (1998a). The entrepreneurial university: Demand and response. Tertiary Education and Management, 4(1), 5-16.

Clark, B.R. (1998b). The entrepreneurial university. Berkeley: University of California Press.

Clark, B.R. (2002). Sustaining change in universities. (First keynote address, 24th European Association for Institutional Research Annual Conference. September 8-11, 2002), Prague, The Czech Republic.

Currie, J., \& Newson, J. (Eds.). (1998). Universities and globalization-critical perspectives. Thousand Oaks, California: Sage Publications.

De la Mothe, J. (1998). Government science and the public interest. In G.B. Doern (Ed.), Government, science and global change. Toronto: University of Toronto Press.

Dobson, I.R. (2001). How has massification changed the shape of Australian universities? Tertiary Education and Management, 7(4), 295-310.

Eastman, J. (2003). Strategic management of universities. CSSHE Professional File, 24, 1-55.

Etakowitz, H., \& Leydesdorff , L. (1997). Universities and the global knowledge economy. London: Cassell Press.

Fram, E. (1972). We must market education - and here are some guidelines for doing so, effectively. Chronicle of Higher Education, April 17.

Hatch, M.J., \& Schultz, M. (2000). Scaling the Tower of Babel: Relational differences between identity, image and culture in organisations. In M. Schultz, M.J. Hatch, \& M.H. Larsen (Eds.) The expressive organization-linking identity, reputation and corporate brand. Oxford: Oxford University Press.

Jencks, C., \& Riesman, D. (1968). The academic revolution. New York: Doubleday.

Kerr, C. (1987). A critical age in the university world: Accumulated heritage versus modern imperatives. European Journal of Education, 22, 183-193.

Kirp, D.L. (2003). Shakespeare, Einstein, and the bottom line: The marketing of higher education. Cambridge, MA: Harvard University Press. 
Krachenberg, A.R. (1972). Bringing the concept of marketing to higher education. Journal of Higher Education, 43, 369-390.

Levitz, R.R., Noel, L., \& Richter, B.J. (1999). Strategic moves for retention success. New Directions for Higher Education, Winter, 31-49.

Lewis, D.R., Hendel, D.D., \& Dundar, H. (2002). Wither private higher education in transition. (Paper presented at the 24th European Association for Institutional Research Annual Conference. September 8-11, 2002). Prague, The Czech Republic.

Marginson S., \& Considine, M. (2000). The enterprise university: Power, governance and reinvention in Australia. Cambridge University Press.

Mount, J., \& Bélanger, C.H. (2001). 'Academia Inc': The perspective of university presidents. The Canadian Journal of Higher Education, 31(2), 135-165.

Murtaugh, P.A., Burns, D.L., \& Schuster, J. (1999). Predicting the retention of university students. Research in Higher Education, 41(3), 355-371.

Newman, J.H. (1947). The idea of a university: Defined and illustrated in nine discourses. London: Longmans. Note: Dates from 1852.

Pascarella, E.T. (Ed.). (1982). Studying student attrition. New Directions for Institutional Research, No. 36, San Fransico: Jossey-Bass.

Ruch, R.S. (2001). Higher education, inc.: The rise of the for-profit university. Baltimore, MD: Johns Hopkins University Press.

Slaughter, S., \& Leslie, L.L. (1997). Academic capitalism: Politics, policies, and the entrepreneurial university. Baltimore, MD: Johns Hopkins University Press.

Soley, L.C. (1996). Leasing the ivory tower: The corporate takeover of academia. Boston, MA: South End Press.

Teichler, U. (1998). Massification: A challenge for institutions of higher education. Tertiary Education and Management, 4(1), 17-27.

Teichler, U. (2001). Mass higher education and the need for new responses. Tertiary Education and Management, 7(1), 3-7.

Terkla, D.G., \& Pagano, M.F. (1993). Understanding institutional image. Research in Higher Education, 34, 11-22. 
Trow, M. (1970). Reflections on the transition from mass to universal higher education. Daedalus, 90(1), 1-42.

van Riel, C.B.M. (1997). Research in corporate communications: An overview of an emerging field. Management Communication Quarterly, 11(2), 288-309.

van Riel, C.B.M. (2000). Corporate communication orchestrated by a sustainable corporate story. In M. Schultz, M.J. Hatch, \& M.H. Larsen (Eds.), The expressive organization-linking identity, reputation and corporate brand. Oxford: Oxford University Press. 